\title{
Prediker, preekgesindheid en die toerusting van die gemeente
}

\author{
F.P. Kruger \& C.J.H. Venter \\ Vakgroep Praktiese Teologie \\ Skool vir Kerkwetenskappe \\ Potchefstroomse Universiteit vir $\mathrm{CHO}$ \\ POTCHEFSTROOM \\ E-pos: fercel@lantic.co.za \\ dmscjhv@puknet.puk.ac.za
}

\begin{abstract}
Preacher, preaching attitude and the equipment of the congregation

Having defined the concepts preacher and preaching attitude, the authors deal with basis-theoretical material, especially material taken from the Pastoral Epistles. In-depth investigation is undertaken of especially expressions in which preaching and the attitude of the minister are stated explicitly. A special section is also devoted to the interrelationship of attitude and the spirituality of the preacher. Finally this article focuses on the attitude of the preacher and his role in the spiritual equipment of the congregation. This exposition is followed by final concretizing perspectives for the praxis of equipment in ministering the Word to the congregation.
\end{abstract}

\section{Inleiding}

In resente homiletiese literatuur vind tans iets van 'n klemverskuiwing plaas in die wetenskaplike besinning oor die prediking. Waar die klem vroeër sterk geplaas is op die preek as preek en die samestellende elemente van 'n preek, val die klem tans sterker op die prediker en ook die gesindheid van die prediker. Twee voorbeelde dien as toeligting van hierdie stelling. Cilliers (1996:1) toon op grond van 'n uitgebreide ondersoek aan dat daar wel inhoudelik onrusbarende tendense in die prediking waargeneem kan word. Hierin speel die persoon en gesindheid van die prediker ook 'n bepaalde rol. Kim (1997:6) gaan selfs verder in sy navorsing en sien 'n oorsaaklike verband tussen dalende lidmaatgetalle en die gesindheid en ingesteldheid van die prediker in sy prediking. 
Uit bogenoemde beredenering blyk die aktualiteit van hierdie onderwerp. Die sentrale doelstelling met hierdie artikel is die byeenbring, ordening en rangskikking van toepaslike materiaal oor prediker en preekgesindheid in die opbou van die gemeente met die oog op die daarstelling van basisteorieë vir verdere besinning oor hierdie tema in die Praktiese Teologie. In hierdie artikel sal in die besonder gefokus word op die ontginning van relevante materiaal uit die Pastorale Briewe. Die motivering vir hierdie fokus is dat die Pastorale Briewe van die mees sentrale openbaring oor prediker, preekgesindheid en die wyse van opbou van die gemeente bevat.

\section{Terminologie}

Binne die raamwerk van die onderwerp moet die begrippe preek/prediker asook preekgesindheid kortliks omskryf word.

\section{- Werksdefinisie van prediking}

Prediking is die proses van brugbou tussen die Bybel en die moderne wêreld waardeur God Drie-enig deur sy geroepe dienskneg tot die gemeente spreek.

\section{- Werksdefinsisie van gesindheid}

Gesindheid dui op die erns, ywer en entoesiasme wat daar bestaan by 'n persoon om 'n bepaalde saak te hanteer of 'n taak af te handel (Anstey, 1991:221).

\section{- Werksdefinisie van preekgesindheid}

Preekgesindheid het te make met 'n bepaalde denkwyse, gevoel en handelingswyse waarmee prediking geskied.

\section{Basisteoretiese verkenning uit die Pastorale Briewe}

\subsection{Prediker}

Kim (1997:38) toon aan dat veral vier begrippe in die Pastorale Briewe gebruik word vir prediker. Vanweë die onderwerp van die artikel sal die begrippe nie bespreek word nie. Ter wille van 'n nadere definisie van wat prediker impliseer, sal enkele basisteoretiese perspektiewe gebied word. Die begrippe word in 1 Timoteus 2:7, 2 Timoteus 1:11 en 2 Timoteus 4:5 aangetref. Die begrippe is die volgende:

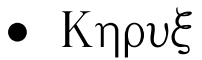
- Aтобтоर̃
- $\Delta$ เ $\delta a \sigma \kappa a \lambda o ̂$ 
- Evar $\gamma \in \lambda \iota \sigma \tau \hat{\eta}$

Bogenoemde begrippe dui in die Pastorale Briewe op die funksie wat die prediker moet verrig. Die volgende konklusie kan op grond van die

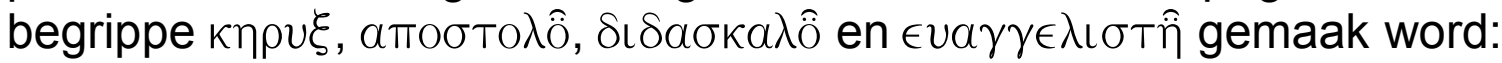

- Die prediker is 'n geroepene van God.

- Die prediker ontvang sy boodskap van God. Die prediker het geen boodskap van sy eie nie. Dit wat aan hom oorgelewer word, moet die prediker verkondig. Die prediker moet klein word agter die boodskap sonder om sy siening bokant die boodskap te verhef.

- Die prediker moet die Woord bedien in die gesindheid van 'n gestuurde.

\subsection{Perspektiewe op gesindheid in direkte verbinding met prediking}

Uit die voorgaande het dit geblyk dat prediking, prediker en gesindheid interafhanklike begrippe is. Venter(1988:152) onderskei nege Woordbedieningsbegrippe in die Pastorale Briewe. Vanweë die omvang van die artikel sal die begrippe vir prediking nie bespreek word nie, maar wel primêr die gesindhede wat op direkte wyse hieraan gekoppel word. In die Pastorale Briewe word veral ses gesindhede op direkte wyse aan die

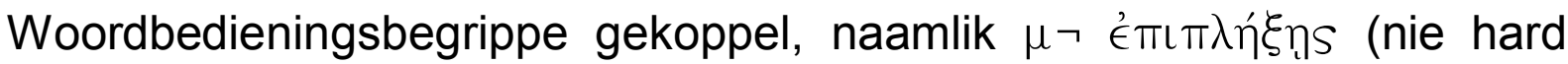

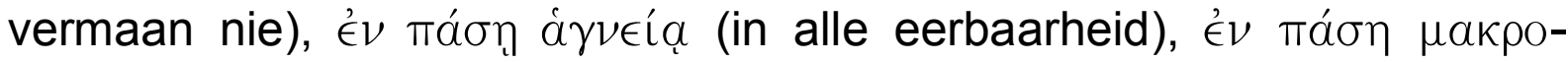

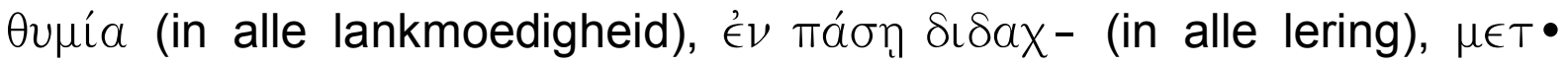

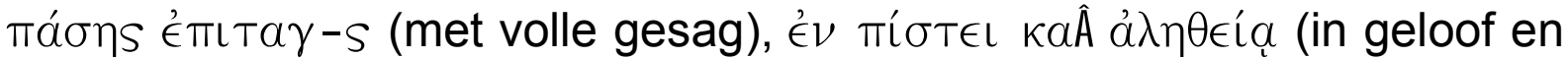
waarheid). Dié aspekte van preekgesindheid wat verband hou met die Woordbedieningsbegrippe verdien verdere bespreking. Die aspekte van die gesindheid kan soos volg ingedeel word:

- Gesindheid wat verband hou met die erns waarin prediking moet geskied.

- Die gesindheid wat verband hou met die inhoud van die prediking.

- Die gesindheid wat verband hou met die wyse van prediking.

\subsubsection{Aspekte van gesindheid wat verband hou met die erns waarin prediking moet geskied}

Twee aspekte van gesindheid in die Pastorale Briewe bied lig op die

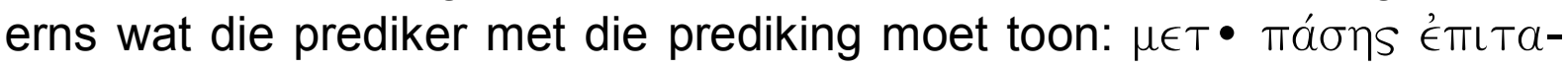

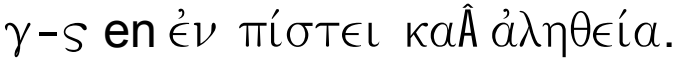




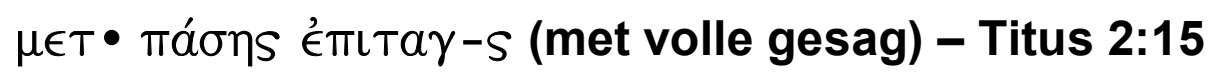

Die begrip erns ( $\epsilon \pi \iota T a \gamma \eta s)$ benadruk die feit dat Titus ooreenkomstig sy opdrag moet vermaan. Die aspek van gesindheid wat hier uitgelig word, is die gesindheid dat Titus in die vermaning so moet optree dat niemand aan sy opdrag kan twyfel nie. Titus moet met ander woorde met groot nadruk optree (Benton, 1997:137). Titus se prediking moet oortuigende prediking wees (Groenewald, 1977:181). In die verkondiging van die Woord moet Titus so optree dat niemand hom verag nie (Guthrie,

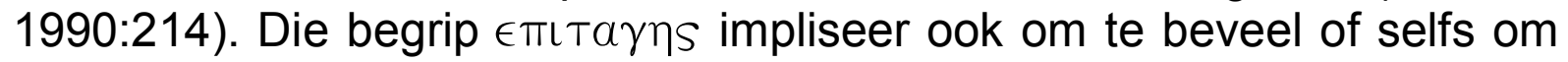
instruksies te gee (Louw \& Nida I, 1989:426). Genoemde semantiese woordeboek plaas die begrip binne die semantiese veld van kommunikasie. Hieruit word die afleiding gemaak dat die prediker ten opsigte van prediking as kommunikasie bewus moet bly van die opdrag tot prediking. Die roepingsbewustheid tot prediking moet daartoe aanleiding gee dat die prediker met erns, met ander woorde met volle oortuiging, die Woord moet verkondig.

Barnard (1994:454) benadruk die feit dat alle prediking moet geskied in die krag van die Heilige Gees. Mense vra in die prediking na dit wat God sê en nie na dit wat die prediker sê nie (Venter, 1996:61; Koornhof, 1993:61). Vanweë die gevaar dat predikers die preekstoel so vol kan staan dat lidmate God nie kan sien nie, pleit Van der Walt (1984:2) vir prediking wat God aan die woord laat kom.

\section{Afleidings}

- Die prediker ontvang die opdrag om die Woord met volle gesag te bedien.

Die begrip met volle gesag is presies die teenoorgestelde van selfverheffing. Die prediker moet klein word agter die Woord wat hy verkondig. Die gesindheid $\mu \epsilon \tau$ è $\pi a ́ \sigma \eta S ~ \epsilon ́ m ı T a \gamma$ gee uitdrukking aan die oortuigingskrag wat met die prediking gepaard gaan. Nieteenstaande omstandighede soos onder andere ervaring of ouderdom moet die Goddelike opdrag (roepingsbewustheid) dien as motivering om die Woord met oortuiging (in alle erns) te verkondig.

- Die prediker moet dit wat hy preek Skriftuurlik begrond anders misbruik hy die geleentheid van prediking.

- Ware gesag is die gesag van Christus wat reëel word in die beloftes en eise van die Woord.

- Prediking met gesag is prediking van die gesag van Christus en daarom prediking van die Woord alleen. 


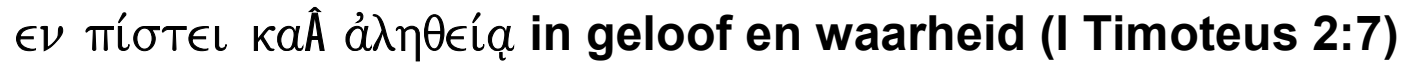

Die frase in geloof en waarheid dui op die sfeer waarin die prediking moet geskied. Stott (1982:262) bespreek dié gesindheid aan die hand van twee perspektiewe. Dié gesindheid dui volgens hom daarop dat die prediker ernstig moet wees en altyd die volgende moet onthou:

- Dit wat hy preek, moet die prediker bedoel en

- dit wat gepreek word moet hy self uitleef.

Vorster (1995:462) benadruk die postmodernistiese lewens- en wêreldbeskouing wat hoë vereistes aan die prediking stel. Teenoor die lewensen wêreldbeskouing wat waarhede wil relativeer, wil die prediking juis vaste waarhede oordra. Predikers moet volgens Vorster nie terugdeins daarvoor om die waarheid van die Woord in geloof oor te dra nie. Richards en Hoeldtke (1980:120) benadruk die impak wat 'n model op mense het. Die gemeente hoor die verkondiging van die Woord, maar sien ook die uitwerking van die Woord in die prediker se lewe raak. Prediking in geloof en waarheid het te make met die geloof wat die prediker het in die waarheid van die Woord wat hy moet bring. Bingle (1987:6) benadruk die noodsaaklikheid daarvan dat die prediker moet glo wat hy sê, want die gemeente voel aan of hy geloofwaardig is al dan nie. Innerlike leegheid word maklik op die preekstoel deursien; daarom moet egte betrokkenheid en geloofwaardigheid iets natuurliks wees en nie iets wat demonstreer word nie. In die lig hiervan praat Bingle van 'n geheiligde individualiteit wat by die prediker moet bestaan (Bingle, 1987:6).

Dié gesindheid bring mee dat die prediker nie uit die hoogte met die gemeente praat nie, maar langs hulle staan, met ander woorde hy is saam met medegelowiges op weg. Sy roeping en taak onderskei hom wel van die gemeente, maar bo alles bly hy eers kind van God.

\section{Afleidings in verband met prediking in geloof en waarheid}

Prediking in geloof en waarheid dien as 'n opdrag aan predikers. Hieronder word die volgende verstaan:

- Die prediker asook die prediking moet deur geloof en waarheid gekenmerk word.

- Die prediker is eers kind van God en dan bedienaar van die Woord.

- Die prediker moet geloof hê in die waarheid van die Woord wat hy verkondig. Vanweë die onthullende aard van die prediking kom die gesindheid van die prediker maklik na vore. 
- Geloofwaardigheid word nie geskep deur in 'n aantal demonstratiewe tegnieke nie. Geloofwaardigheid het te make met 'n innerlike gesindheid van geloof in dit wat verkondig word.

\subsubsection{Gesindheid wat verband hou met die inhoud van prediking - 2 Timoteus 4:2}

Die gesindheid wat verband hou met die inhoud van die prediking is $\left.\epsilon^{\prime} V \pi \alpha ́ \sigma \eta\right\rceil \delta \delta \alpha \chi \eta$ (in alle lering). Dié lering dui in die Pastorale Briewe op 'n gevestigde dogma of leer waarin 'n persoon gelei moet word (Brown, 1986:770). Guthrie (1990:178) is van mening dat dié woord dui op die kennis en insig in God se Woord. Leer is 'n aanduiding van instruksie wat op formele wyse of selfs informele wyse kan geskied; dit dui dus op onderrig (Louw \& Nida I; 1989:413). Louw en Nida I (1989:389) plaas die begrip $\delta \iota \delta a \times \eta$ as 'n subdomein onder die begrip kommunikasie. Hieruit word afgelei dat die lering binne die kommunikatiewe verhouding tussen prediker en lidmaat voltrek word.

Sagmoedigheid en lering hang in 2 Timoteus 4:2 nou saam en is bepalend vir mekaar (Bentley, 1997:285). Lering in lankmoedigheid beteken nie dat vrede gemaak word met die verkeerde standpunte nie. Choi (1994:81) het in sy studie op deeglike wyse aangetoon dat die prediker 'n kommunikatiewe persoonlikheid moet hê. Die prediker as kommunikator moet lidmate daarom in die gesindheid van "alle lering" vermaan.

Volgens Bentley (1997:285) moet die prediker ingestel wees daarop om die gemeente op 'n versigtige wyse toe te rus. Predikers ervaar dikwels 'n misnoë met die sigbare uitwerking van die prediking. Een van die vernaamste oorsake hiervan is 'n gebrek aan noukeurige onderrig of toerusting (Bentley, 1997:285). Die prediker se vernaamste instrument in toerustende prediking is die Bybel self (Benton, 1997:63).

\section{Afleidings}

Lering word binne die kommunikatiewe verhouding tussen prediker en lidmaat voltrek. Lerende prediking is toerustend van aard. Toerustende prediking moet lidmate motiveer tot 'n vroom en Christelike lewe. Die waarheid van die Bybel vorm die inhoud van toerustende prediking. Hiermee word die gevaar van selfgesentreerdheid by die prediker afgewys. In lerende prediking is die mens met sy konteks nie die uitgangspunt nie, maar wel die mikpunt. 


\subsubsection{Aspekte van gesindheid wat verband hou met die wyse van prediking}

In die Pastorale Briewe word die volgende aspekte van gesindheid aangetref wat te make het met die wyse van prediking: $\mu$ " $\epsilon \pi \iota \pi \lambda \eta \dot{\eta} \xi S$

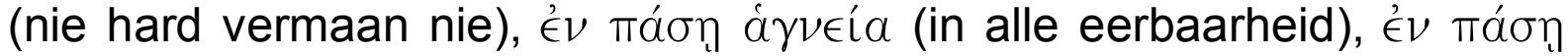

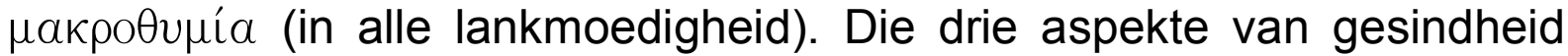
benadruk drie perspektiewe in die wyse van prediking, naamlik onderskeidingsvermoë in die prediking, die waardigheid in prediking en die geduld waarin prediking moet geskied.

\subsubsection{1 Timoteus 5:1 - $\mu^{*} \dot{\epsilon} \pi ı \pi \lambda \eta ́ \xi \eta s$ (nie hard vermaan nie)}

Die begrip $\epsilon \pi L \pi \lambda \eta \sigma \sigma \omega$ beteken om te vermaan of selfs om die strengste afkeur teenoor 'n bepaalde saak te kenne te gee (Louw \& Nida I; 1989:436). Opmerklik is die konteks waarin die begrip gebruik word. In die bediening van die Woord moet Timoteus bedag wees op die natuurlike onderskeidings in die onderskeie leeftydsgroepe. 'n Ouer man moenie op 'n ruwe wyse en uit die hoogte aangespreek word nie (Fee, 1988:103). Hieruit blyk dat die prediker in die bediening van die Woord ingestel moet wees op natuurlike onderskeidings. Indien ouer persone vermaning of teregwysing nodig het, moet dit in die regte gesindheid geskied. Guthrie (1990:119) beklemtoon die feit dat Timoteus nie uit eerbied vir die ouderdom die vermaning agterweë mag laat bly nie. In 'n verhouding van seun tot vader moet die vermaning geskied.

Die agtergronde en verwagtinge van die verskillende leeftydsgroepe is tydens die erediens verskillend (Dingemans, 1991:58; Craddock, 1985: 91). Genoemde outeurs benadruk in die tipologie van die hoorders die volgende sake:

- Predikers moet let op die ambivalente situasie van hoorders.

- Mense is op weg in 'n proses. Elke hoorder staan êrens op die weg wat die Heilige Gees met hom volg.

- Mense van verskillende leeftydsgroepe het volgens die teorie van Maslow verskillende behoeftes. Indien dié behoeftes nie bevredig word nie, skep dit frustrasie. Mense het hiervolgens die drang om hulle self te verwesenlik.

- Prediking moet daarom die hoorders help om self in gesprek met God te kom. Die prediker moet lidmate van alle ouderdomsgroepe hiertoe in staat stel.

Die gesindheid wat in dié begrip na vore gebring word, is dié van omgang met die gemeente op pastorale wyse (Barnard, 1994:33). 
Pastorale prediking behels dat die prediker in 'n verhouding met die lidmaat moet staan. Prediking moet daarom in 'n persoonlike, individuele en sorg klimaat geskied (Barnard, 1994:33).

\section{Afleidings}

Bogenoemde gesindheid vereis veral onderskeidingsvermoë van die prediker.

Die prediker moet let op die volgende:

- Binne elke gemeente bestaan 'n diversiteit mense met verskillende agtergronde, ouderdomme en behoeftes. Die prediker moet lidmate van verskillende ouderdomsgroepe in die regte gesindheid vermaan. Ouer lidmate moet nie te hard, met ander woorde in arrogansie vermaan word nie, terwyl jonger lidmate soos broers en susters vermaan moet word.

- Die gesindheid wat in die begrip nie hard vermaan nie beklemtoon word, is dié van pastorale omgang met die gemeente. Pastorale prediking veronderstel 'n verhouding tussen prediker en gemeente. Een van die kenmerke van pastorale prediking word in die gesindheid hierbo saamgevat naamlik prediking wat in ' $n$ milieu van persoonlike en individuele aandag plaasvind.

- Die gesindheid van nie te hard nie neem niks van die erns van vermaning weg nie, maar wys wel op die regte wyse waarop vermaning moet geskied.

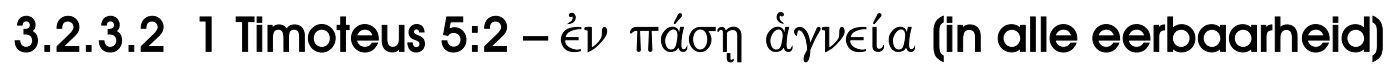

Dié begrip impliseer om sonder morele gebreke te wees of om rein te wees (Louw \& Nida I; 1989:746). Bentley (1997:284) lig die gedagte uit dat die begrip a $\gamma \nu \in\llcorner$ a waarsku teen die gevaar van verkeerde gedagtes asook gevolgtrekkings. Die gedragsreël wat Paulus aan die jongman Timoteus deurgee, geld vir die verhouding teenoor 'n bejaarde man, bejaarde vroue asook jonger vroue. Die vermaning moet geskied in 'n gesindheid van reinheid. Die prediker moet in die prediking waak teen onsuiwere bedoelings asook gedagtes. Zwanenburg (1971:100) benadruk die gedagte dat die gesindheid van in alle reinheid dui op 'n kuise waardigheid. Die prediker moet persoonlik en in die prediking op 'n kuise en waardige manier met alle mense kan omgaan. 


\section{Afleidings ten opsigte van prediking in alle eerbaarheid}

Prediking moet in alle eerbaarheid geskied. Predikers moet in die voorbereiding asook die lewer van preke waak teen verkeerde gedagtes en gevolgtrekkings. Predikers loop die gevaar om hulle eie gevoelens deur die prediking te projekteer deur middel van woedebuie en 'n hoogmoedige aanslag tot die prediking. Prediking in alle nederigheid is prediking wat in 'n kuise waardigheid teenoor alle mense geskied, terwyl die wese van ware prediking in gedagte gehou word.

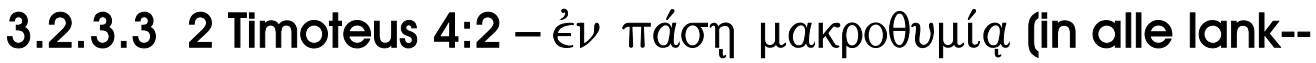 moedigheid)}

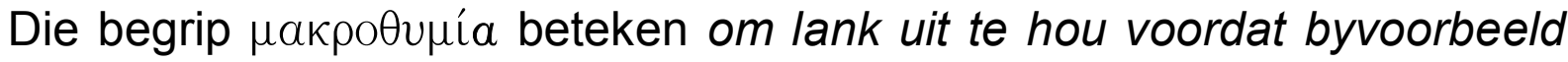
aan woede toegegee word (Douglas, 1986:883). Die begrip vorm een van die subdomeine van gesindhede (Louw \& Nida I, 1989: 289) en dui op 'n staat van emosionele kalmte selfs te midde van provokasie en irritasie (Louw \& Nida I, 1989:307). Fee (1988:285) stem hiermee saam en meen dat dié begrip dui op die geduld en selfbeheersing van dié prediker.

Vanuit die bespreking van bogenoemde outeurs blyk dit dat die term

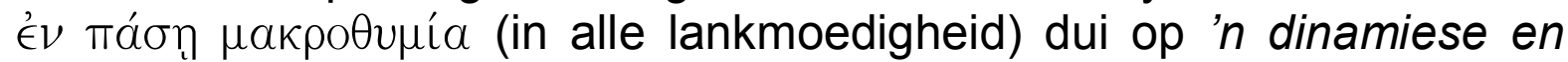
aktiewe daad eerder as 'n blote passiewe daad van geduldig wees. In 2 Timoteus 3:10 hou Paulus selfs sy lankmoedigheid onder alle omstandighede aan die jong leraar Timoteus voor as voorbeeld. Bentley (1997: 285) benadruk die gedagte dat geduld nie daarop dui om swakheid en sonde oor die hoof te sien nie.

In alle lankmoedigheid dui dus direk op die wyse waarop gepreek moet word (Guthrie, 1978:166). Die prediker moet geduld in die prediking beoefen (Douglas, 1986:883). Die prediker moet geduld met sy eie asook ander persone se swakhede hê (Hendriksen, 1983:311). Op grond van ' $n$ toenemende gevoel van frustrasie en onbehae ontwikkel predikers maklik 'n negatiewe gesindheid (Louw, 1987:57). Dikwels is 'n oordrewe vorm van entoesiasme die wortel van dié toedrag van sake. Louw (1987: 57) sien al hierdie onrealistiese verwagtings as simptome van uitbranding wat uitloop op 'n fase van apatie of onverskilligheid. Predikers ervaar dikwels die teleurstelling dat hoe harder hulle werk aan die prediking, hoe minder kry hulle menslik gesproke uitgerig. Die teleurstelling vanweë die onmag om doeltreffend tot mense deur te dring, gee sodoende aanleiding tot ' $n$ bedieningskrisis. Die predikant se moedeloosheid gaan maklik oor in 'n negatiewe gesindheid teenoor die gemeente. In die lig hiervan moet predikers rekening hou daarmee dat hulle die Woord bring tot mense wat reeds lank voordat hy met hulle in aanraking gekom het, onder die leiding van die Heilige Gees staan. Hoorders het 
met ander woorde elkeen 'n eie geskiedenis met God (Dingemans, 1991:49). Daarom moet die prediker lidmate help om in gesprek met God te kom (Dingemans, 1991:50).

\section{Afleidings ten opsigte van prediking in alle geduld}

Geduld dui op die emosionele kalmte waarmee die prediker die Woord moet bedien. Egte prediking is Skrifprediking wat aan 'n teks verbonde is. Die prediker het die taak om te vertolk en nie om sy eie sienings te verkondig of af te dwing nie. Die eintlike prediker is die Heilige Gees en daarom mag die prediker nooit in die weg hiervan staan nie. Die prediker moet in geduld rekening hou daarmee dat die Heilige Gees ook in lidmate se lewens besig is met sy werking. Die prediker is geroep as bedienaar van die Woord en hierby moet hy homself hou.

\subsection{Gesindheid verbind met sekere metafore in die Pastorale Briewe}

Volgens De Klerk (1976:12) figureer veral vier metafore in die Pastorale Briewe wat die gesindheid van die prediker belig. Kragtige terme word gebruik om aspekte van die gesindheid wat die prediker moet besit, aan te dui. Die begrippe is:

- Oıкоvоно̂̃ (Titus 1:7)

- $\Sigma T \rho a t i \omega t \hat{\eta}$ (2 Timoteus 2:3),

- $\alpha \theta \lambda \pm(2$ Timoteus 2:5),

- $\gamma \in \omega \rho \gamma \in \mathrm{F}(2$ Timoteus 2:6)

\subsection{1 Оıкоионоิ}

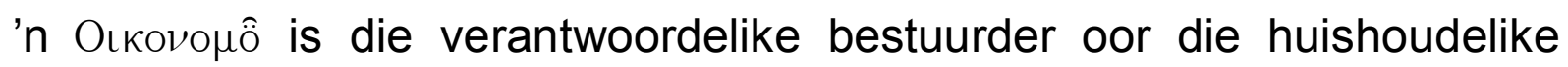
sake waaroor hy aangestel is (De Klerk, 1976:12). Die taak van rentmeester of opsiener bring groot verantwoordelikheid mee. Die gemeente word voorgestel as die huisgesin van God. Hierin moet rentmeesters beheer uitoefen en toesien dat alles ordelik geskied (Benton, 1997:44). Dié begrip dui op die persoon wat in beheer is van 'n huishouding amper soos 'n bestuurder (Louw \& Nida I, 1989:521). Die bedienaar van

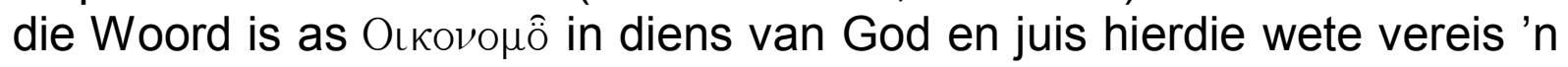
gesindheid van verantwoordelikheid en onberispelikheid (De Klerk, 1976:13).

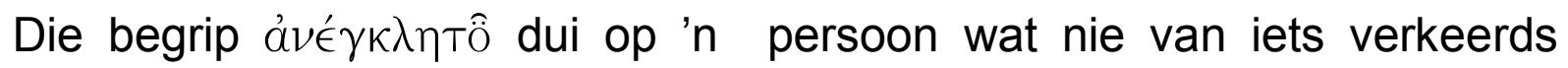
beskuldig kan word nie (Louw \& Nida I; 1989:438). Die gedagte is sekerlik nie dat van die prediker verwag word om sonder sonde te wees nie. Die wyse waarop die prediker sy opdrag as bestuurder uitvoer, moet bo alle verdenking wees. Die prediker moet iemand wees met 'n goeie 
naam na binne en na buite op grond van sy lewenswandel. Venter (1988:150) bied 'n duidelike perspektief hierop deur daarop te wys dat die prediker 'n voorbeeld moet wees in gedrag; hy moet toon dat hy vanuit die Woord leef. Verder moet die prediker in sy lewenswandel 'n gesindheid openbaar waarin hy homself in diensbaarheid offer aan die gemeente deur onberispelik te wees. In die wyse waarop die prediker die Woord sny en in sy lewenswandel uitleef, behoort sy gesindheid tot voorbeeld van almal te strek (Venter, 1988:150).

\section{Afleiding:}

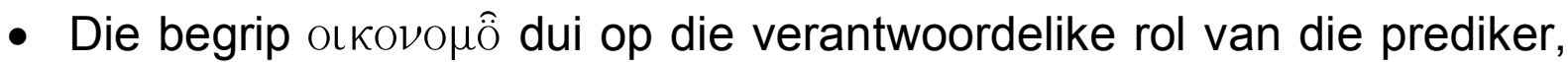
naamlik om in die gesindheid van rentmeester te werk. 'n Rentmeester word deur God oor sy huisgesin aangestel.

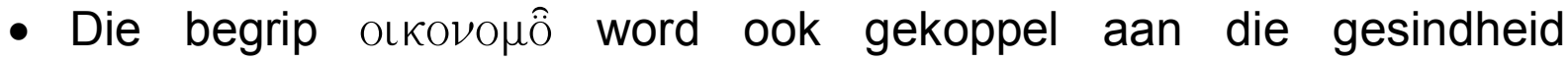

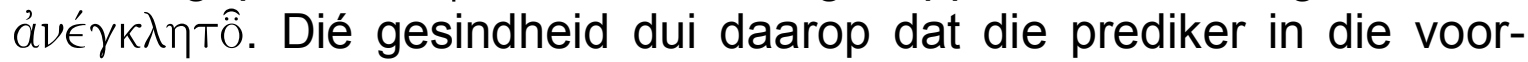
beeld wat hy met Woordverkondiging asook sy lewenswandel stel, nie vatbaar vir enige aanklag moet wees nie. Die prediker moenie verdink word van 'n slegte karakter staan nie. $\mathrm{Na}$ binne sowel as na buite moet die prediker as voorbeeld dien.

- Die aspekte van 'n gesindheid beïnvloed die prediker op die volgende wyse:

- Die prediker moet beheersd wees in sy lewensvoorbeeld sowel as in sy prediking.

- Die prediker moet vashou aan die Woord van God, sowel in sy eie lewe asook in die prediking.

- Die prediker moet opbouend preek. Die prediker moet deur die prediking lidmate saamneem en hulle aanmoedigend op die weg van die geloof begelei.

- Die prediker moet weerleggend preek. Op dié wyse moet prediking 'n duidelike beginselraamwerk vir die lewe van gelowiges stel waarin hulle leer om prinsipieel te lewe.

- Die prediker se optrede op die preekstoel sowel as in sy omgang met mense moet getuig van 'n deurleefde verhouding met God.

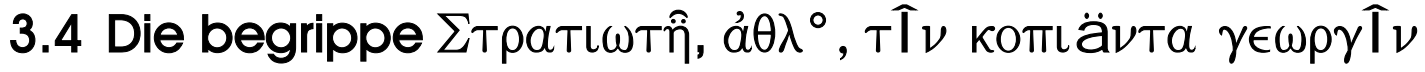

Dié begrippe dui op die geloofsvolharding van die prediker (De Klerk, 1976:13). In 2 Timoteus 2:3-6 word melding gemaak van 'n soldaat, 
atleet en landbouer. Bogenoemde drie beelde lig bepaalde fasette van die gesindheid van prediker uit, naamlik:

- Die beeld van die soldaat benadruk die vereistes vir prediking, naamlik:

- Die bereidheid om ter wille van die verkondiging van die Woord swaar te kry.

- Getrouheid aan die roeping waartoe hy geroep is.

- Die vaardigheid (kompetensie) om die wapen van God se Woord te kan hanteer.

- Die beeld van die atleet dui op die reëls wat in ag geneem moet word met die uitsig op die oorwinnaarskroon.

- Die beeld van die boer benadruk die gesindheid van harde arbeid verbonde aan die prediking. Die harde arbeid gaan immers die loon vooraf.

\section{Afleidings}

Die volgende basisteoretiese afleidings kan oor bogenoemde begrippe gemaak word:

- Vier metafore in die Pastorale Briewe omlyn die gesindheid van die

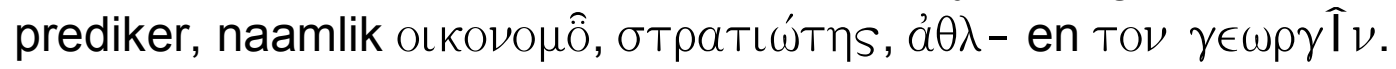

- Die ampsdraer is 'n nietige bedienaar van 'n verantwoordelike diens. Daarom moet die ampsdraers aan besondere eise voldoen. Vanuit bogenoemde vier begrippe blyk die volgende ten opsigte van die gesindheid van die ampsdraer :

- Die prediker is 'n leerouderling met die besondere opdrag om die Woord te verkondig.

- Drie aspekte van gesindheid word in die vier begrippe verduidelik, naamlik dié van onberispelik wees (dُ $\left.\hat{\epsilon}^{\prime} \gamma \kappa \lambda \eta T O \nu\right)$, dié van in selfverloëning - dus om voluit beskikbaar te wees om die Woord te bly verkondig - en bereidwilligheid om hard te werk aan die prediking.

Die metafore van bestuurder, soldaat, atleet en boer beklemtoon weereens die wees-funksie van die prediker. Vanuit die wees-funksie, vloei die doen-funksie voort wat getuig daarvan dat dit in prediking nooit om eie belange draai nie. Prediking moet God immers aan die woord laat kom. 


\section{Die gesindheid en spiritualiteit van die bedienaar}

In die vorige paragraaf is die aandag gevestig op die persoonlike geloofsverhouding van die prediker met God. Daar is aangetoon dat die erns, ywer en entoesiasme om die Woord te verkondig, voortspruit uit die wete dat die regte gesindheid 'n gawe van God is. Dit is daarom noodsaaklik om te besin oor die band tussen spiritualiteit en preekgesindheid.

Spiritualiteit dui op 'n deurleefde verhouding met God wat neerslag vind in die mens se totale bestaan en vergestalt word in alle verhoudinge.

Floor (1993:294) wys in sy studie op die volgende aspekte rondom spiritualteit:

- Spiritualiteit het te make met 'n bepaalde wyse van geestelike lewe.

- In spiritualiteit gaan dit om 'n bepaalde grondhouding wat gewortel is in die verhouding tot God. Spiritualteit is 'n bepaalde houding (gesindheid) van die mens teenoor God. Die gesindheid (houding) is een van oorgawe aan God en toewyding aan sy diens.

- Spiritualiteit is daarom nie dieselfde as geloof nie. Dit is wel 'n bepaalde uiting of belewing van die geloof.

Velema (1993:379) toon op grond van 2 Timoteus 3:17 aan dat roeping die prediker innerlik aanvuur tot die oefening van sy spiritualiteit. Die uiterlike roeping, naamlik God wat die prediker tot 'n bepaalde diens roep, moet innerlik met gewilligheid beantwoord word. In dié opsig is dit vanselfsprekend dat die gewilligheid alleen deur die inwerking van die Heilige Gees kan geskied. Die spiritualiteit van die prediker kom langs die weg van roepingsbesef tot sy reg.

In 2 Timoteus 4:7b-8 benadruk Paulus die noodsaak van geestelike oefening in kontras met fisiese oefening. Die metafoor oefening $(\gamma \nu \mu \nu \alpha \zeta \epsilon)$ is 'n term wat nie vreemd aan 'n gimnasium is nie. Oefening gaan met opoffering en moeite gepaard. Die oefening in die $\epsilon \cup \sigma \in \beta \in l \alpha$ (godsvrug of toewyding aan God) gaan ook in die prediker se lewe met opoffering gepaard. Fee (1988:105) benadruk die feit dat oefening in die godsvrug nie tevergeefs is nie. Die oefening het waarde vir die tydelike asook die ewige lewe.

Burger (1995:57) toon in sy navorsing aan dat gesindheid nie uit boeke aangeleer word nie. Gesindhede word van ander mense aangeleer en nageleef. Burger kom daarom tot die gevolgtrekking dat die prediker se modellering in dié opsig noodsaaklik is. 
Spesifieke aspekte van gesindheid moet beoefen word in die prediking. Dié aspekte kan slegs binne die persoonlike verhouding van die prediker met God tot hulle reg kom. Spiritualiteit as geestelike oriëntasie van die mens gee rigting aan die beoefening van dié aspekte van gesindheid. In die prediking moet die prediker homself verantwoord oor sy geestelike oriëntasie. Op dié wyse dien spiritualiteit die dubbele gerigtheid soos hierbo aangetoon, naamlik as karakterisering van die geestelike bestaanswyse asook die stimulering hiervan. Kim (1997:164) het aangetoon dat die spiritualiteit van die prediker nie vanselfsprekend kom nie. Selfs nie eers die feit dat die predikant prediker van die Woord is, maak spiritualiteit iets outomaties nie. Hierin moet die prediker homself oefen. Kim (1997:165) toon twee noodsaaklike elemente in die beoefening van spiritualiteit aan, naamlik:

- Die prediker moet God se Woord voortdurend inneem. Dingemans (1991:14) het die prediker as hoorder onder die hoorders beskryf. Die prediker hoor die Woord op presies dieselfde wyse as die hoorders, naamlik as gelowige wat stry teen die sonde. Tog is die prediker die eerste hoorder wat deur middel van studie dieper in die Woord gedelf het in die voorbereiding. Dingemans (1991:14) noem die prediker selfs die "Anwalt seiner Hörer".

- Die gebed is noodsaaklik vir 'n deurleefde geestelike navolging van God. Die gebeure rondom prediking moet biddend geskied.

\section{Afleidings ten opsigte van die spiritualiteit van die prediker en preekgesindheid}

Die spiritualiteit van die prediker en preekgesindheid is onlosmaaklik aan mekaar verbonde. Hieruit blyk die volgende:

- Die prediker moet homself voortdurend oefen in spiritualiteit. Die prediker moet homself oefen deur gereelde Bybelstudie, die bestudering van die Woord en 'n deurleefde gebedslewe.

- Die spiritualiteit van die prediker, met ander woorde die egte en deurleefde verhouding met God gee rigting aan die beoefening van gesindheid teenoor ander mense.

- Die prediker moet hom in die beoefening van sy spiritualiteit altyd deur die Woord laat lei. In die beoefening van spiritualiteit moet die prediker ook rekening hou met sy betrokkenheid in die wêreld, alhoewel hy nie deur die werklikheid van die lewe oorheers mag word nie. Daarom moet die prediker in die beoefening van verskillende aspekte van preekgesindheid hom ook deur die Woord laat lei. Die 
regte aspekte van preekgesindheid vloei voort vanuit 'n egte en deurleefde spiritualiteit.

\section{Gesindheid van die prediker en die toerusting van die gemeente}

Burger (1995:17) toon aan dat die kerk in oorgangstye leef. Daar is egter 'n wins aan oorgangstye verbonde - gelowiges word gedwing om skerper waar te neem en skerper te dink. Burger toon ook aan dat gelowiges in oorgangstye buitengewoon sensitief moet wees vir die stem van die Here en dat die prediker in die toerusting sterker op menseverhoudings ingestel moet wees. Hieronder verstaan hy die volgende (Burger, 1995:60):

- Deel wees van geloofsgemeenskap. Die prediker moet die posisie inneem van by die gemeente in plaas van teenoor die gemeente.

- Daar wees by. Die prediker moet tussen en saam die gemeente leef.

- Lief wees vir. Die prediker as toeruster kan alleenlik sy taak verrig indien hy werklik omgee vir lidmate.

- Entoesiasties wees oor. Die prediker moet te midde van oorgangstye die geleenthede raaksien om die Woord te kan bedien.

In 1 Timoteus 1:12-17 word benadruk dat dit in Paulus se bediening om een saak gaan - die enigste vaste fondament van die Woord waarop die gemeente verder toegerus kan word (Müller, 1993:19). Dié perikoop sluit in 1 Timoteus 1:17 af met 'n doksologie. Die doelwit van die prediking is daarom om God se lof te besing. Daarom moet die verkondiging van die Woord altyd uitloop op die lofsang op dit wat God doen. Volgens Müller (1993:23) moet die kerk onder alle omstandighede klankbord en klankversterker van die doksologiese noot wees. Smit (1995:12) en Van der Merwe (1995:140) beklemtoon die vername rol wat die prediker in dié verband vervul. Aan die hand van vier begrippe word die prediker se rol hierin verduidelik:

- Presensie. Die prediker moet in opregtheid sy roeping vervul as gestuurde. Die begrip verduidelik die dáárwees van die prediker.

- Visionering. Die prediker moet lidmate help om vanuit die Woord te dink en leef. Die prediker moet lidmate help om visie te skep.

- Fasilitering. Die prediker moet lidmate help om maniere te vind wat hulle lewe met mekaar en hulle bedieninge in die wêreld kan bevorder. 
- Energie-ontsluiting. Die prediker moet bydra daartoe om die energie binne die gemeente te help ontsluit.

Koornhof (1993:63) toon op grond van 2 Timoteus 3:17 aan dat die toets vir die prediker se regte omgang met die Woord opgesluit lê in die kweek van die regte lewenswyse. Deur gereelde omgang (oefening) met die Woord word die prediker toegerus vir sy opdrag om die Woord te bedien. Venter (1988:151) benadruk op grond van 1 Timoteus 4:6-8 die prediker se verantwoordelikheid ten opsigte sy eie geloofslewe. Die gebruik van

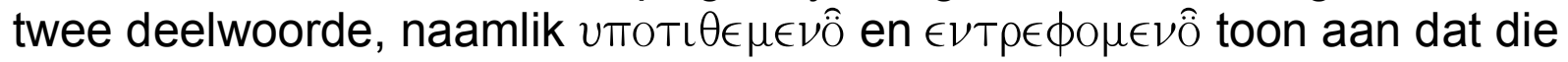
twee aksies van selfvoeding en gemeentevoeding in voortdurende wisselwerking met mekaar staan. Dié voeding moet plaasvind met 'n konstante inname van die Woord (Guthrie,1978:106).

Vorster (1998:20) dui op sy beurt ook die toerustingstaak van die predikant aan. Toerusting moet in die bediening van die predikant ' $n$ prioriteit wees. Vorster (1998:23) onderskei vir die prediking drie voorwaardes wat toerustend van aard moet wees:

- Prediking moet waarlik Skrifprediking wees. Die verskillende Woordbedieningsbegrippe in die Pastorale Briewe getuig hiervan.

- Prediking moet 'n sterk onderrigtende inslag hê wat wyer strek as die sogenaamde leerstellige prediking. Hiermee bedoel Vorster dat prediking onderrig in alle opsigte moet wees. Op Sondag moet die gelowige leer wat om gedurende die week te doen - prediking moet die implikasies vir die gelowige se lewe aandui.

- Prediking moet die individu op aktuele wyse betrek. Toerustende prediking het dus vele dimensies. Toerustende prediking moet vertroostend, bemoedigend, appelerend, rigtinggewend en vermanend van aard wees.

Vorster (1992:462) het in sy navorsing aangetoon dat eise aan die prediking in die teenswoordige kultuur van verandering gestel word. Daarom is die vraag nie of daar nog gepreek moet word nie, maar wel hoe daar gepreek moet word sodat die moderne mens kan hoor. Vanuit die verhouding tussen preekgesindheid en spiritualiteit blyk dit dat die prediker homself eers moet voed in sy eie geloofslewe, want dan sal hy ook die gemeente kan voed.

Uit bogenoemde blyk dit dat die prediker lidmate met sy prediking beïnvloed. Die prediker moet bedag wees op sy preekgesindheid. Dit vra eerlike en voortdurende selfondersoek. Die prediker mag nooit die oorsaak daarvan wees dat verkeerde gesindhede in die weg van God se Woord staan nie. Die prediker moet daarom let op die sentrale open- 
baring vanuit die Pastorale Briewe rondom die konsep van preekgesindheid. Die prediker moet in verantwoordelikheid werk aan die vorming van die regte preekgesindheid selfs te midde van oorgangstye.

\section{Finale samevatting}

In die Pastorale Briewe is die herder-apostel besig om jong herderleraars advies te gee oor die versorging van die kudde. Hiermee saam word advies gegee aan predikers oor die prediking.

- Nege Woordbedieningsbegrippe word in die Pastorale Briewe aangetref. Die begrippe word aan sekere aspekte van gesindheid gekoppel waarin die Woordverkondiging moet geskied. Ses aspekte van gesindheid word in die Pastorale Briewe op direkte wyse aan die prediking verbind, naamlik $\mu \eta \dot{\epsilon} \pi\left\llcorner\pi \eta \xi \hat{\eta}\right.$ (nie hard vermaan nie), $\epsilon^{\prime} v$

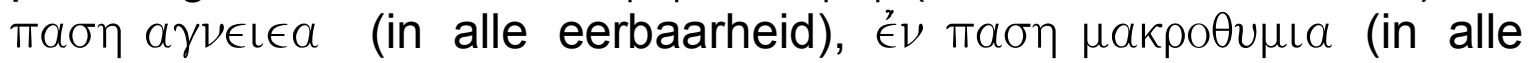

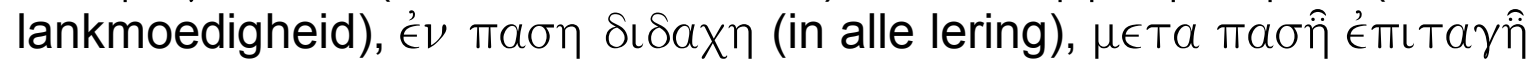
(met volle gesag), $\epsilon^{\prime} \nu \pi \iota \sigma T \in \iota$ kal $\alpha \lambda \eta \theta \in \iota \alpha$ (in geloof en waarheid). Dié aspekte van gesindheid het te make met die volgende:

- Die erns van prediking. Twee aspekte van gesindheid gaan hiermee gepaard. Die vereiste van in alle eerbaarheid dui op die gesindheid waarvolgens die prediker klein word agter die boodskap wat hy verkondig. Die roepingsbewustheid van die prediker moet as motivering dien om die Woord met oortuiging (in alle erns) te verkondig. Die vereiste van in geloof en waarheid benadruk die feit dat die prediker geloof moet hê in die waarheid wat hy verkondig;

- Die inhoud van die prediking. Die gesindheid wat die inhoud van die prediking benadruk, word uitgedruk deur die frase in alle lering. Lerende prediking is toerustend van aard. Die waarheid van die Woord vorm die inhoud van die toerusting;

- Die wyse van prediking. Drie aspekte van gesindheid gaan hiermee gepaard. Die vereiste van nie hard vermaan nie benadruk die gesindheid van pastorale omgang met die gemeente. Pastorale prediking veronderstel 'n verhouding tussen prediker en gemeente. Die vereiste van in alle eerbaarheid dui op die gesindheid waarin predikers moet waak teen verkeerde gedagtes en gevolgtrekkings. Predikers moet waak daarteen om hulle eie gedagtes ten koste van die Woord in die prediking te projekteer. Prediking in alle lankmoedigheid benadruk die gesindheid van emosionele kalmte waarin die prediker die Woord moet bedien. 
- Vier metafore word in die Pastorale Briewe gebruik vir bepaalde

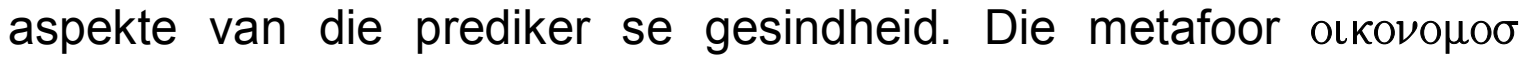
(bestuurder) benadruk die gesindheid van rentmeesterskap van die prediker. Deur Woorverkondiging asook lewenswandel moet die prediker vir die gemeente 'n voorbeeld wees. Die metafoor $\sigma T \rho \alpha \tau L \omega T \hat{\eta}$ (soldaat) benadruk die feit dat die prediker bereid moet wees om swaar te kry ter wille van die prediking. Die metafoor $\alpha \theta \lambda \eta$ (atleet) benadruk die gesindheid van getrouheid in die prediking. Die metafoor $\gamma \in \omega \rho \gamma \hat{̂}$ (landbouer) benadruk die gesindheid van inspanning wat met prediking gepaard gaan. Die gesindheid van harde arbeid moet deur die prediker nagevolg word.

- Bogenoemde aspekte van gesindheid en die metafore wat daarvoor gebruik word, benadruk die feit dat gesindheid nie in die prediking weggesteek kan word nie. Die aspekte van gesindheid en die metafore wat daarvoor gebruik word, veronderstel deurgaans 'n positiewe preekgesindheid waardeur mense toegerus en begelei word. Preekgesindheid oefen ' $n$ invloed uit op die preekvoorbereiding, preeklewering asook die gesindheid van die gemeente teenoor prediking.

\section{Konkretiserende perspektiewe met die oog op die praktyk}

Die gesindheid van die prediker het implikasies vir die prediker se bediening:

- Die prediker moet in preekvoorbereiding die bedoeling van die Bybel ernstig opneem. Die Bybel is nie bedoel om 'n blote studie-objek te wees nie. Die Bybel is die Woord van God. Die prediker moet daarteen waak om deur die preek tot die gemeente te spreek oor God se Woord. Prediking wat nie getuig van die erns om God aan die woord te laat kom nie, is nie ware prediking nie. Indien die prediking God aan die woord laat kom, verkry dit geloofwaardigheid.

- Eers wanneer die prediker self deur die Woord getref is en hy vir homself preek, kan God se Woord deur hom tot die gemeente spreek. Daarom verg preekvoorbereiding erns en dissipline van die prediker. Die prediker moet homself ruim geleentheid gun om biddend oor die boodskap van die teks te mediteer.

- Prediking besit 'n onthullende aard. Die prediker se gesindheid teenoor die prediking en gemeente word weerspieël in die wyse waarop preke voorberei word. Die prediker moet waak daarteen dat gebeure gedurende die week van voorbereiding (persoonlik sowel as binne die gemeente) nie sy ingesteldheid ten opsigte van prediking nadelig raak nie. Verskillende sake kan die prediker in sy tekskeuse 
beïnvloed. Die prediker moet homself hieroor verantwoord sodat tekskeuse nooit in vooroordele verval nie. Geestelike agterstande binne die gemeente, die huidige nuusgebeure en persoonlike probleme by die prediker is enkele sake wat maklik aanleiding gee tot 'n preek wat reeds vooraf uitgewerk is, terwyl die prediker in sy meditasie net na 'n geskikte teks soek. Die prediker kan nie anders as om biddend te worstel om die verligting van die Heilige Gees in die proses van preekvoorbereiding nie. Dit is verder nodig dat die prediker teks en gemeentesituasie saam oordink. Dié proses vereis gereelde kontak met die gemeente, insig in die probleme en vreugde van die gemeente asook insig in resente gebeure.

- Ware prediking is teksprediking. Die prediker moet in sy keuse asook in die lewering van die preek aan die teks gebonde bly. In die voorbereiding van preke worstel die prediker om presies vas te stel wat God sê.

- Die prediker moet in die tekskeuse homself in nederigheid verloën. Die prediker se gesindheid beïnvloed sy tekskeuse. 'n Nederige gesindheid van luister na wat die Woord sê, het prediking tot gevolg wat bly by wat God se Woord sê. Daar bestaan 'n wisselwerking tussen die prediker se getroue omgaan met die Woord by wyse van eksegese en die lewer van die preek. Die prediker wat in die proses van eksegese homself op getroue wyse oopgestel het vir die Woord, ervaar die vrymoedigheid of positiewe gesindheid om hieroor te preek.

- Die prediker moet as 'n man van verhouding gekenmerk word ten opsigte van sy verhouding tot God, sy biddende omgaan met die Woord asook in sy verhouding met die gemeente. Die verhouding met die gemeente word met persoonlike kontak (waaronder huisbesoek, siekebesoek asook pastorale bearbeiding) verdiep en verinnig.

- Die regte preekgesindheid oefen 'n invloed uit op die lewer van 'n preek. Hieruit vloei die volgende voort:

- Die prediker se woorde, gebare, voorkoms en styl beïnvloed die gemeente in die kommunikasieproses wat voltrek word in die prediking. Predikers sê dikwels een ding, maar hul nie-verbale kommunikasie weerspreek dit. Alhoewel die prediker mens is, moet hy in sy preeklewering let op die wyse waarop hy die preek oordra. Hy moet homself vooraf reg ondersoek om sodoende nie uit blote pligspleging die Woord te bedien nie. 
- Die prediker mag nie toelaat dat irrasionele denke en gevoelens hom sodanig oorheers dat sy prediking verval in eensydige prediking nie. Hieronder word verstaan prediking wat voortdurend een bepaalde saak wil inhamer. Alles wat in die prediker se weg staan, moet hy sover moontlik betyds uit die weg ruim deur opbouende gesprekke.

- Die amen van die prediker aan die einde van die preek dui nie op die einde van die preek nie. Die gemeente moet ook in hulle harte of hardop amen hierop kan sê. Die preekgesprek dien as hulpmiddel om die gemeente te help om op die prediking amen te kan sê. Preekgesprekke tydens vergaderings asook op 'n gereelde basis na afloop van eredienste kan dien as vertrekpunt waarvolgens die saak gehanteer kan word.

- Die prediker moet die kuns aanleer om nie oordrewe sensitief vir kritiek te wees nie. Die prediker moet onderskeidingsvermoë aanleer. Dit behels dat die prediker die gemeente moet ken en dienooreenkomstig bereid moet wees om sy foute te erken.

- Die prediker moet daarteen waak om outoritêr in die prediking oor te kom. Hy moet homself maan daarteen om die prediking as "onkritiseerbaar" te beskou. Net so moet die prediker ook waak teen 'n onderskatting van die prediking. Die gemeente se behoeftes en siening mag nooit die krag van die teks vervang nie.

- Die prediker moet die gemeente toerus of skool in die wyse waarop sinvolle preekbesprekings gehou kan word. In dié opsig kan vraelyste vooraf asook na afloop van die prediking 'n waardevolle bydrae lewer om vas te stel of die prediking doelmatig na lidmate oorgekom het.

- Die prediker wat gereeld huisbesoek en pastorale besoeke doen, leer mettertyd om kritiek te weeg. In dié opsig moet die prediker in die gesindheid van onderskeidingsvermoë te werk gaan.

Die gesindheid van die prediker speel dus 'n vername rol in die toerusting van die gemeente. Die gesindheid van die prediker moet daartoe bydra om lidmate toe te rus vir hulle alledaagse lewe.

\section{Bibliografie}

ANSTEY, M. 1991. Negotiating conflict. Kaapstad : Shepherds Press.

BARNARD, A.C. 1994. In die kragveld van die Woord en Gees. Pretoria : Fourie \& Malitz.

BENTLEY, M. 1997. Passing on the truth. I \& II Timothy simply explained. Darlington : Bath Press. 
BENTON, J. 1997. Straightening out the self-centred church. The message to Titus. Darlington : Bath Press.

BINGLE, P.W. 1987. God se tolk in die taalvelde van die mens. In die Skriflig, (83)29, Sept.

BROWN, C. 1986. Didage. (In The New International Dictionary of the New Testament Theology. Michigan : Zondervan Publishing House. p. 764.)

BURGER, C.W. 1995. Gemeentes in transito. Vernuwingsgeleenthede in 'n oorgangstyd. Kaapstad : Lux Verbi.

CHOI, J.C. 1994. The preacher as communicator. Potchefstroom : PU vir $\mathrm{CHO}$. (Th.M. - thesis.)

CILLIERS, J. 1996. Die uitwissing van God op die kansel. Ontstellende bevindinge oor Suid-Afrikaanse prediking. Kaapstad : Lux Verbi.

CRADDOCK, F.B. 1985. Preaching. Nashville : Abingdon Press.

DE KLERK, W.J. 1975. Pastorale sensitiwiteit. Johannesburg : Perskor.

DINGEMANS, G.D.J. 1991. Als hoorder onder de hoorders. Kampen : Kok.

DOUGLAS, J.D. 1986. Makrothumia. (In New Bible Dictionary. Wheaton : Callenbach. p. 883.)

FEE, G.D. 1988. I \& II Timothy, Titus. (New International Biblical Commentary.) Massachusetts : Paternoster Press.

FLOOR, L. 1993. De spiritualiteit van de charismatici. (In Balke, W., Exalto, K., Van Driel, L. \& Van 't Spijker, W., red. Spiritualiteit. Kampen : De Groot Goudriaan. p. 294-305.)

GROENEWALD, E.P. 1977. Die Pastorale Briewe. Kaapstad : Nasionale Boekdrukkery.

GUTHRIE, D. 1978. The Pastoral Epistles. (Tyndale New Testament Commentaries.) Michigan : Eerdmans.

GUTHRIE, D. 1990. The Pastoral Epistles. (Tyndale New Testament Commentaries.) Michigan : Eerdmans.

HENDRIKSEN, W. 1983. 1 \& 2 Thessalonians, 1 \& 2 Timothy and Titus. (New Testament Commentary.) Edinburgh : Billy.

JONKER, W.D. 1976. Die Woord as opdrag. Pretoria : N.G Kerkboekhandel.

KIM, H.K. 1997. Preacher and spirituality: A diaconiological study in the light of the Pastoral Epistles. Potchefstroom : PU vir CHO. (Th.M. dissertation.)

KOORNHOF, J.J.E. 1993. Prediking van II Timoteus 3:10-17. (In Burger, C.W., Muller, B.A. \& Smit, D.J., reds. Riglyne vir prediking oor die Pastorale en Algemene Briewe. Kaapstad : Lux Verbi. p. 57-68.)

LOUW, D.J. 1987. Bediening en bedienaar. (In Combrink, H.J.B., Muller, B.A., reds. Huldigingsbundel opgedra aan prof. J.L. de Villiers. Pretoria : Lux Verbi. p. 5571.)

LOUW, J.P. \& NIDA, E.A. 1989. Greek English lexicon of the New Testament (II). New York : United Bible Studies.

MÜLLER, B.A. 1993. Prediking van I Timoteüs 1:12-17. (In Burger, C.W., Müller, B.A. \& Smit, D.J., reds. Riglyne vir prediking oor die Pastorale en Algemene Briewe. Kaapstad : Lux Verbi. p. 19-27.)

RICHARDS, L.O. \& HOELDTKE, C. 1980. A theology of church leadership. Michigan : Zondervan.

SMIT, A. 1995. Nuut gedink oor leierskap in gemeentes. (In Burger, C., Hendriks, J., Van der Merwe, M. \& Smit, A. reds. Gemeente en bediening. Nuut gedink oor leierskap in gemeentes. Die begeleiding van 'n Christelike gemeenskap. Kaapstad : Lux Verbi. p. 16-36.)

STOTT, R.W. 1982. I believe in preaching. London : Hodder and Stoughton. 
VAN DER MERWE, M. 1995. Nuwe treë saam met God. Riglyne en programme oor spiritualiteit en gemeentevernuwing. Kaapstad : Lux Verbi.

VAN DER WALT, J.J. 1984. God aan die Woord. Potchefstroom : Departement Diakoniologie, $\mathrm{PU}$ vir $\mathrm{CHO}$.

VELEMA, W.H. 1993. Spiritualiteit in aktie. (In Balke, W., Exalto, K., Van Driel, L. \& Van 't Spijker, W., reds. Spiritualiteit. Kampen : De Groot Goudriaan. p. 416424.)

VENTER, C.J.H. 1988. Die Gees, die Woord en die bedienaar van die Woord. (In Coetzee, J.C., red. Koninkryk, Gees en Woord. Pretoria : N.G. Kerkboekhandel. p. 141-162.)

VENTER, C.J.H. 1996. Uitkringende liefdesbetoon. Pretoria : R.G.N. Uitgewery.

VORSTER, J.M. 1992. Die eise aan die gereformeerde prediking in die teenswoordige kultuur van verandering. Hammanskraal : Hammanskraalse Teologiese Skool.

VORSTER, J.M. 1995. Vernuwing in die prediking in die lig van hedendaagse lewensbeskoulike tendense. In die Skriflig, 29(1):443-466, Maart.

VORSTER, J.M. 1998. Die toerustingstaak van die Gereformeerde predikant: 'n praktiese bedieningsmodel. In die Skriflig, 32(1):19-35, Jan.

VOS, C.J.A. 1994. Die blye tyding. Homiletiek uit 'n hermeneuties-kommunikatiewe perspektief. Pretoria : RGN Uitgewery.

ZWANENBURG, L.G. 1971. Leer ambt en leven. Paulus brieven aan Timoteus. Amsterdam : Ton Bolland.

\section{Kernbegrippe:}

aspekte van die prediker se gesindheid (1 Tim. 5:2; 2 Tim. 4:2)

metafore vir gesindheid (bestuurder, soldaat, atleet, boer)

Pastorale Briewe

prediking, die prediker se gesindheid

prediking - as toerusting van die gemeente

\section{Key concepts:}

aspects of the preacher's attitude (1 Tim. 5:2; 2 Tim. 4:2)

metaphors for attitude (manager, soldier, athlete, farmer)

Pastoral Epistles

preaching, the preacher's attitude

preaching - as equipping the congregation. 